Review

\title{
Clinical Relevance of Natural Killer Cells Following Hematopoietic Stem Cell Transplantation
}

\author{
Jeanne M Palmer ${ }^{1,2}$, Kamalakannan Rajasekaran ${ }^{1}$, Monica S Thakar ${ }^{1,3}$ and Subramaniam Malarkannan ${ }^{1,2} \llbracket$ \\ 1. Laboratory of Molecular Immunology, Blood Research Institute, 8727 Watertown Plank Road, Milwaukee, WI 53226, USA; \\ 2. Departments of Medicine, Medical College of Wisconsin, Milwaukee, WI 53226, USA; \\ 3. Departments of Pediatrics, Medical College of Wisconsin, Milwaukee, WI 53226, USA.
}

$\triangle$ Corresponding author: Jeanne M Palmer, jpalmer@mcw.edu or Subramaniam Malarkannan, subra.malar@bcw.edu.

() Ivyspring International Publisher. This is an open-access article distributed under the terms of the Creative Commons License (http://creativecommons.org/ licenses/by-nc-nd/3.0/). Reproduction is permitted for personal, noncommercial use, provided that the article is in whole, unmodified, and properly cited.

Received: 2012.10.23; Accepted: 2012.12.01; Published: 2012.12.05

\begin{abstract}
Natural killer (NK) cells are one of the first cells to recover following allogeneic hematopoietic stem cell transplantation (HSCT), and are believed to play an important role in facilitating engraftment or preventing post-transplant infection and tumor recurrence. Recent studies have provided novel insights into the mechanisms by which NK cells mediate these highly clinically relevant immunological functions. In particular, the ability of NK cells to reduce the risk of graft versus host disease (GVHD) and increase the graft versus leukemia effect (GVL) in the setting of human leukocyte antigen (HLA)-haploidentical HSCT highlights their clinical potentials. NK cells also mediate anti-viral protection, in particular against cytomegalovirus (CMV), an infection that causes significant morbidity and mortality following transplant. Another crucial function of NK cells is providing protection against bacterial infections at the mucosal barriers. NK cells achieve this by promoting anti-microbial defenses and regeneration of epithelial cells. These recent exciting findings provide a strong basis for the formulation of novel NK cell-based immunotherapies. In this review, we summarize the recent advances related to the mechanisms, functions, and future clinical prospects of NK cells that can impact post-transplant outcomes.
\end{abstract}

Key words: Natural killer cells, immunological functions, stem cell, post-transplant

\section{Introduction}

NK cells protect against a variety of cancers and infections ${ }^{1}$. NK cells develop in the bone marrow and constitute about $5-10 \%$ of total lymphocytes in the peripheral circulation and secondary lymphoidal organs. Effector functions of NK cells include direct natural cytotoxicity, antibody-dependent cellular cytotoxicity (ADCC), as well as secretion of inflammatory cytokines and chemokines that indirectly regulate the functions of other immune cells ${ }^{2,3}$. These effector functions are mediated through multiple independent activation receptors expressed on NK cells. Recent studies have revealed that NK cells also provide unique immunological assistance for the regen- eration of tissues, such as epithelial cells ${ }^{4}$.

As one of the first lymphocyte populations to recover $^{5,6}$, NK cells play an important role in immune reconstitution following HSCT. NK cells both modulate the immune system as well as mediate direct killing of malignant or infected cells. Conventional human NK cells are identified by the expression of CD56, NKp46 and by the absence of CD3. Other cell surface receptors commonly expressed in NK cells fall within three families. They are, 1) killer immunoglobulin like receptors (KIR), 2) NKG2A-C that form a heterodimer with CD94, and NKG2D, which is expressed as a homodimer and relies on DAP10 and 
DAP12 adaptor proteins, and 3) natural cytotoxicity receptors (NCR) (Table 1). Although other NK-like subsets that share functions with conventional NK cells have been recently described ${ }^{7,8}$, for the purpose of this review article, we will focus on conventional NK cells.

\section{NK cell subset specifications and its rel- evance in bone marrow transplantation}

NK cell development occurs in the bone marrow. The association of distinct effector functions with unique NK cell subsets is thought to be developmentally regulated ${ }^{9,10}$, which refers to the 'education' or 'licensing' of NK cells. This early maturation process is shown to be strictly dependent on the expression of inhibitory KIR by the developing NK cells. Many of the KIR molecules recognize HLA class I molecules as their cognate ligands. Thus, the process of education occurs through the ligation of an inhibitory KIR with its respective MHC class I ligand expressed on the bone marrow stromal cells. This interaction with the self MHC sets an activation threshold and 'educates' the NK cell to have a 'fixed' cytotoxic potential ${ }^{11}$. When tumor transformation or pathogen infection leads to a reduction or absence of MHC class I, the set activation threshold of the NK cells overcomes the inhibition to mediate the killing of the target cells. In the event this education does not occur, the NK cell will not have potent cytotoxic activity, and will become tolerant and inactive. Recent studies have shown that this failure to educate can be overcome by viral infections ${ }^{12}$ or by cytokine activation with IL- $15^{13}$. The mechanism by which this occurs has yet to be investigated; however, a role of 'induced-self' ligands is of high probability.

Table I. Common Cell Surface Markers for Conventional NK Cells.

\begin{tabular}{|c|c|}
\hline Killer IG-like (KIR)- Inhibitory & Ligands \\
\hline KIR2DL1 & Group 2 HLA-C \\
\hline KIR2DL2 & Group 1 HLA-C \\
\hline KIR2DL3 & HLA-C1-Asn80, HLA-B*73, -B*46 \\
\hline KIR2DL5 & Unknown \\
\hline KIR3DL1 & HLA-Bw4 \\
\hline KIR3DL2 & HLA-A3, -A11 \\
\hline KIR3DL7 & Unknown \\
\hline \multicolumn{2}{|l|}{ Killer IG-like (KIR)- Activating } \\
\hline KIR2DS1 & HLA-C2-Lys80 (weak) \\
\hline KIR2DS2 & HLA-C1-Asn80 (weak) \\
\hline KIR2DL4 & HLA-G \\
\hline \multicolumn{2}{|l|}{ Heterodimeric C-type Lectin receptors- Inhibitory } \\
\hline CD94/NKG2A/B & HLA-E \\
\hline NKG2D* & MICA, MICB, ULBP-1, -2, -3 \\
\hline \multicolumn{2}{|l|}{ Heterodimeric C-type Lectin receptors- Activating } \\
\hline CD94/NKG2C & HLA-E \\
\hline CD94/NKG2E/H & HLA-E, Qa-1b \\
\hline \multicolumn{2}{|l|}{ Natural cytotoxicity receptors (NCR) } \\
\hline NKp30 & B7h6, BAT3, HCMV-pp65 \\
\hline NKp46 & Hemagglutinin \\
\hline NKp44 & Hemagglutinin \\
\hline \multicolumn{2}{|l|}{ Activating co-receptors } \\
\hline FcүRIII (CD16) & Fc of IgG \\
\hline CD2 & CD58 (LFA-3) \\
\hline LFA-1 & ICAM-1 \\
\hline 2B4 & CD48 \\
\hline NKp80 & Activation-induced C-type lectin \\
\hline CD69 & Unknown \\
\hline CD40 Ligand & CD40 \\
\hline
\end{tabular}


NK cell subsets are classified based on phenotypic or functional differences. Although NK cells can fall into distinct categories based on their KIR (human) or Ly49 (mouse) expression, the functional relevance of these subsets has yet to be determined. KIRs are markers that are imperative in regulating interactions between NK and other cells. All cells in the body express human leukocyte antigen (HLA) class I receptors, including A, B and C. HLA-B and HLA-C function as ligands for specific KIRs (Table 1). The extracellular portions of KIR are homologous, regardless of whether they are activating or inhibiting. However, the intracellular portion of KIR contains either an immunoreceptor tyrosine-based activation motif (ITAM) or immunoreceptor tyrosine-based inhibition motif (ITIM). KIR are able to detect 'missing-self', or 'induced-self', which helps the NK cell mediate an attack against transformed, infected, or foreign (donor) cells. Additionally, KIR expression may help predict anti-viral immunity ${ }^{14}$ and anti-tumor effects ${ }^{15}$. Other NK cell receptors that regulate their interactions with target cells include the heterodimer lectin receptors NGD2A-C, which associate with CD94, as well as the homodimeric NKG2D. These can be inhibitory (NKG2A) or activating (NKG2C or NKG2D). NKG2C is important in mediating defense against $\mathrm{CMV}^{16,17}$, and NKG2D has been shown to mediate anti-tumor effects ${ }^{18}$.

Current studies indicate that based on their functional abilities, human NK cells can be divided into two major subsets, CD56 $6^{\text {bright }} \mathrm{CD} 16^{\mathrm{dim}}$ and CD56 ${ }^{\text {dim }}$ CD16 bright. ${ }^{19}$ In the mouse, the analogous NK subsets are identified by CD27bright CD11bdim and CD27dimCD11b bright, respectively ${ }^{19}$. The CD56 dim compromise $90 \%$ of peripheral NK cells and are more effective at mediating cytotoxicity using granzyme B, perforin, FasL and TRAIL, or $\mathrm{ADCC}^{3}$. The CD56 ${ }^{\text {bright }} \mathrm{CD} 16^{\text {dim }}$ constitute only a minority of the total NK cells, and produce immuno-regulatory cytokines $^{3}$. These CD56 $6^{\text {bright }}$ CD16 ${ }^{\text {dim }}$ NK cells are thought to be precursors to the CD56 ${ }^{\mathrm{dim}} \mathrm{CD} 16^{\text {bright }} \mathrm{NK}$ subset ${ }^{20}$.

\section{Donor-derived NK cell maturation and functions following HSCT in patient's body}

Donor-derived NK cell recovery following HSCT has been extensively studied, and has provided a novel way to study the ontogeny of NK cells, as well as to increase our understanding regarding the influences of KIR expression and maturation on clinical outcomes. Even in the setting of fully matched HLA transplants, there is a high likelihood that KIR genes are mismatched ${ }^{21-23}$. In unrelated transplants, this likelihood increases, as only $0.24 \%$ of unrelated individuals will have matching $\mathrm{KIR}^{21,22}$. The phenotypic maturation of NK cells following transplant appears to follow a specific pattern. Regulation of maturation can be mediated by the status of KIR ligand matching $^{24,25}$, infections ${ }^{16,26}$, and cytokines ${ }^{13}$. Initially, an expansion of CD56 bright cells has been described; these cells display an immature phenotype as evidenced by high expression of NKG2A/CD94 heterodimer ${ }^{27-29}$. Following that, acquisition of KIR, NKG2C, NKG2D and CD57 occur ${ }^{21,22,24,27,30-33}$. KIR expression is modulated by several factors, including KIR haplotype ${ }^{21}$, surrounding HLA class I molecules ${ }^{30,34}$ and intrinsic genetic factors that regulate KIR expression ${ }^{35}$. Within six months to a year, the NK cells will frequently have a more conventional phenotype, and will often revert to that of the donor ${ }^{21,27,33}$.

NK cells following HLA-haploidentical or half-matched HSCT significantly reduces the relapse of acute myeloid leukemia (AML) ${ }^{22}$, decreased $\mathrm{GVHD}^{36-40}$, improved engraftment and the overall survival as reported by some groups ${ }^{36,37,41}$. When this principle was applied to other types of transplants (Table 2) the results have varied significantly ${ }^{42-44}$. In some studies, KIR-ligand mismatches demonstrate an improved overall survival ${ }^{45,46}$, however, this wasn't observed in other studies ${ }^{43,47-49}$. In the majority of studies, KIR-ligand mismatch was associated with increased acute GVHD ${ }^{47,50}$. Several studies demonstrate a reduced risk of relapse with missing KIR-ligand ${ }^{37,}$ 50-52 ; however, one study demonstrated an increase in relapse ${ }^{53}$.

Table 2. KIR matching and GVHD outcomes.

\begin{tabular}{|l|l|l|l|l|l|l|l|}
\hline Reference & N= & NK cell marker & $\begin{array}{c}\text { T replete }+ \\
\text { T deplete- }\end{array}$ & $\begin{array}{c}\text { Transplant } \\
\text { type }\end{array}$ & relapse & GVHD & TRM/OS/NRM \\
\hline $\begin{array}{l}\text { Cooley et al. } \\
201040\end{array}$ & 1409 & Haplotype- & + & MA & $\begin{array}{l}\text { Less relapse with } \\
\text { B/B in AML only } \\
\text { (not ALL) }\end{array}$ & & \\
\hline & & A/A & & URD & & & \\
\hline & & & & & & \\
\hline & B/B & & & & & \\
\hline
\end{tabular}




\begin{tabular}{|c|c|c|c|c|c|c|c|}
\hline $\begin{array}{l}\text { Venstrom et al } \\
2010^{107}\end{array}$ & 1087 & $\begin{array}{l}\text { KIR3DS1 copy } \\
\text { number }\end{array}$ & + & URD & No difference & $\begin{array}{l}\text { Less GVHD with } \\
\text { more copies of } \\
\text { KIR3DS1+ }\end{array}$ & $\begin{array}{l}\text { Improved TRM with } \\
\text { more KIR3DS1 }\end{array}$ \\
\hline \multirow[t]{2}{*}{$\begin{array}{l}\text { Brunstein et } \\
\text { al.2009 } 38\end{array}$} & 257 & KIR-L mismatch & - & $\begin{array}{l}\text { UCB- RIC } \\
\text { and MA }\end{array}$ & No difference & MA- no difference & $\begin{array}{l}\text { MA- no difference in } \\
\text { TRM + OS }\end{array}$ \\
\hline & & (KIR-L-MM) & ATG & & & $\begin{array}{l}\text { NMA- higher } \\
\text { aGVHD with mis- } \\
\text { match }\end{array}$ & $\begin{array}{l}\text { NMA- worse TRM and } \\
\text { OS with MM }\end{array}$ \\
\hline \multirow[t]{4}{*}{$\begin{array}{l}\text { Cooley et al. } \\
2009108\end{array}$} & 448 & $\begin{array}{l}\text { Haplotype B/x } \\
\text { vs A/A }\end{array}$ & + & URD & $\begin{array}{l}\text { Less relapse with } \\
\text { B/x vs A/A }\end{array}$ & $\begin{array}{l}\text { aGVHD - no differ- } \\
\text { ence }\end{array}$ & Less TRM with $\mathrm{B} / \mathrm{x}$ \\
\hline & & & & MA & & $\begin{array}{l}\text { cGVHD- higher with } \\
B / x\end{array}$ & \\
\hline & & & & 209-match & & & \\
\hline & & & & 239- MM & & & \\
\hline \multirow[t]{2}{*}{$\begin{array}{l}\text { Giebel et al } \\
200935\end{array}$} & 100 & $\begin{array}{l}\text { Outcomes based } \\
\text { on KIR expres- } \\
\text { sion, and KIR } \\
\text { MM }\end{array}$ & - & $\begin{array}{l}\text { MRD + } \\
\text { URD }\end{array}$ & $\begin{array}{l}\text { KIR2DS5 MM high- } \\
\text { er relapse }\end{array}$ & $\begin{array}{l}\text { aGVHD higher with } \\
\text { KIR2DS1 MM }\end{array}$ & $\begin{array}{l}\text { OS- worse with } \\
\text { KIR2DS1-HLA-C MM }\end{array}$ \\
\hline & & & ATG & & & & \\
\hline \multirow[t]{2}{*}{$\begin{array}{l}\text { Willemze et al. } \\
2009109\end{array}$} & 218 & KIR-L MM & - & $\mathrm{UCB}$ & $\begin{array}{l}\text { Less relapse with } \\
\text { KIR-L MM }\end{array}$ & No difference & $\begin{array}{l}\text { Improved OS and LFS } \\
\text { with KIR-L MM }\end{array}$ \\
\hline & & & ATG & MA & & & \\
\hline $\begin{array}{l}\text { Miller et al } \\
2007^{39}\end{array}$ & 2042 & KIR-L MM & Unk & URD & $\begin{array}{l}\text { Less relapse with } \\
\text { KIR-L MM }\end{array}$ & $\begin{array}{l}\text { Increased aGVHD } \\
\text { with KIR-L MM }\end{array}$ & \\
\hline Chen et al 2006 & 131 & Missing KIR-L & + & MRD & No difference & No difference & $\begin{array}{l}\text { Worse OS if donor and } \\
\text { recipient with different } \\
\text { activating KIR }\end{array}$ \\
\hline \multirow{2}{*}{$\begin{array}{l}\text { Farag et al } \\
2006^{110}\end{array}$} & 1571 & KIR-L MM & Both & URD & No difference & No difference & No difference \\
\hline & & & & MA & & & \\
\hline \multirow[t]{2}{*}{$\begin{array}{l}\text { Beelen et al } \\
2005^{111}\end{array}$} & 374 & KIR-L MM & + & MRD /URD & $\begin{array}{l}\text { Less relapse with } \\
\text { KIR-L MM }\end{array}$ & No difference & No difference \\
\hline & & & & MA & & & \\
\hline $\begin{array}{l}\text { Hsu et al } \\
2005^{112}\end{array}$ & 178 & $\begin{array}{l}\text { Inhibitory } \\
\text { KIR-L missing }\end{array}$ & Other & MRD & $\begin{array}{l}\text { In AML/MDS- less } \\
\text { relapse with missing } \\
\text { inhibitory KIR-L }\end{array}$ & & $\begin{array}{l}\text { Improvement in DFS, } \\
\text { and OS with missing } \\
\text { inhibitory KIR-L }\end{array}$ \\
\hline $\begin{array}{l}\text { Schaffer et al } \\
2004^{37}\end{array}$ & 190 & KIR-L MM & Both & Both & $\begin{array}{l}\text { Decreased relapse } \\
\text { with KIR-L MM }\end{array}$ & $\begin{array}{l}\text { More GVHD with } \\
\text { KIR L MM }\end{array}$ & $\begin{array}{l}\text { Inferior OS, increased } \\
\text { TRM with KIR-L MM }\end{array}$ \\
\hline $\begin{array}{l}\text { Bornhauser et } \\
\text { al } 2004^{41}\end{array}$ & 118 & KIR-L MM & Both & Both & $\begin{array}{l}\text { Increase relapse } \\
\text { with KIR L MM }\end{array}$ & $\begin{array}{l}\text { More GVHD with } \\
\text { KIR L MM }\end{array}$ & $\begin{array}{l}\text { Inferior OS and TRM } \\
\text { with KIR-L MM }\end{array}$ \\
\hline $\begin{array}{l}\text { Giebel et al } \\
2003^{34}\end{array}$ & 130 & KIR-L MM & $\begin{array}{l}\text { T de- } \\
\text { plete-ATG }\end{array}$ & URD, MA & $\begin{array}{l}\text { Decrease relapse } \\
\text { with KIR-L MM }\end{array}$ & No difference & $\begin{array}{l}\text { Improved OS, reduced } \\
\text { TRM }\end{array}$ \\
\hline $\begin{array}{l}\text { Davies et al } \\
2003^{36}\end{array}$ & 175 & KIR-L MM & Both & Both & No difference & No difference & $\begin{array}{l}\text { Improved OS if NO } \\
\text { KIR-L MM }\end{array}$ \\
\hline
\end{tabular}

URD: Unrelated donor, MRD: Matched related donor, MA: Myeloablative, RIC: reduced intensity conditioning, UCB: umbilical cord blood, AML: acute myelogenous leukemia, ALL: acute lymphocytic leukemia, MDS: myelodysplastic syndrome, KIR-L MM: KIR-ligand mismatch, OS: overall survival, DFS: disease free survival, TRM: treatment related mortality, aGVHD: acute graft versus host disease, cGVHD: chronic graft versus host disease.

To be able to critically compare the different studies, it is important to understand specific parameters that were used in each one of these studies. For example, earlier studies did not look specifically at the genotype or phenotype of donor KIR, but rather missing KIR ligand ${ }^{54}$. In this case, the high resolution typing of HLA-C and HLA-B were performed and grouped into one of four categories to determine if there are correlating inhibitory KIR, and if so how many. For example, HLA-C group 1 alleles ( $\operatorname{Ser}^{77}$ and $\mathrm{Asn}^{80}$ ) are recognized by KIR2DL2 and 2DL3; HLA-C group 2 alleles $\left(\mathrm{Asn}^{77}\right.$ and $\mathrm{Lys}^{80}$ ) are recognized by KIR2DL1; HLA-Bw4-positive alleles (Arg79, Ile ${ }^{80,}$ $\mathrm{Arg}^{83}$ or $\mathrm{Arg}^{79}, \mathrm{Thr}^{80}, \mathrm{Arg}^{83}$ ) are recognized by KIR3DL1; and Bw6-positive alleles (Arg79, $\mathrm{Asn}^{80}$, Gly ${ }^{83}$ ), have no known ligands for any inhibitory KIR. 
In this model, patients are grouped according to homozygosity for HLA-C group 1, HLA-C group 2, or HLA-Bw6. Under the assumption that an individual has a full complement of inhibitory KIRs, patient homozygosity for HLA-C group 2 indicates lack of ligand for donor inhibitory KIR2DL2 or 2DL3; patient homozygosity for HLA-C group 1 implies lack of ligand for donor inhibitory KIR2DL1; and patient homozygosity for HLA-Bw4 implies lack of ligand for donor inhibitory KIR3DL1 ${ }^{37}$. As technology improved and additional tools were available, the focus switched more to the presence of activating or inhibitory KIRs. This can be performed in several ways. First is to analyze for absence or presence of KIRs through genotyping, in which case the genomic DNA for KIR is assessed. This can be simplified by considering two major haplotypes of KIR molecules based on gene content: haplotype $\mathrm{A}$ and haplotype $\mathrm{B}^{55}$. Haplotype A contains minimal activating KIR molecules, many inhibitory KIR; this haplotype is found in around $60 \%$ of the Caucasian population, and the majority of the Japanese population ${ }^{55}$. Haplotype B contains the inhibitory KIR, as well as multiple activating $\mathrm{KIR}^{55,23}$. Although genotyping is a reliable method of analyzing KIR, it is important to keep in mind that genotype is not always congruent with phenotype $^{21,33}$. However, even if the differences of analysis of NK cells with regards to transplant outcome are taken into consideration that still does not completely explain the wide variations in the clinical outcomes.

One potential explanation for this differential effect of NK cells on transplant outcome may relate to the clinical conditions of the transplant. There appear to be several transplant related variables that regulate NK cell development, including T-cell depletion (TCD) and recipient HLA-C/KIR ligand. One study comparing TCD and $\mathrm{T}$ cell replete transplants, demonstrates that the percentages of NK cells were similar in both conditions; however, the KIR expression was higher in patients who had a TCD transplant $^{56}$. Similar observations have been made in HLA-haploidentical transplants, where TCD grafts are very frequently used ${ }^{37,38,57}$. This may be explained by the lack of competition for cytokines as a result of $\mathrm{T}$ cell depletion ${ }^{58}$; therefore, allowing for more rapid NK cell maturation. However, other studies suggest that NK cell reconstitution is slower in the setting of $\mathrm{TCD}^{13}$, or not affected ${ }^{24}$. The presence or absence of matching KIR ligand may also impact NK cell reconstitution. For example, following transplant, increased cytotoxic activities were observed in those patients who have matching KIR ligands ${ }^{9,}$, , suggesting NK cells require education in order to attain maximum function. Additionally, matching KIR ligand can also improve IFN- $\gamma$ secretion following HSCT, a response that is enhanced by increasing numbers of matching KIR-KIR ligand ${ }^{31}$. Moreover, missing KIR ligand has been shown to be associated with improved clinical outcomes following transplant, which is thought to be mediated by NK cells ${ }^{36,37,50,37}$. Some of these differences may be attributed to the method by which the functionality was assessed ${ }^{13}$; however, there are likely multiple mechanisms by which these interactions regulate NK cells. NK cell function may also be influenced by medications given in the post HSCT setting including cyclosporine, rapamycin, FK506 and mycophenolate, which are frequently used for GVHD prophylaxis ${ }^{59-61}$. In summary, we conclude there are many factors that drive donor-derived NK cell maturation and function in the host. Detailed studies are required to exploit the beneficial effects of NK cells in the clinical setting.

\section{Allogeneic bone marrow transplantation and NK cell-mediated anti-viral immun- ity}

The importance of NK cells in anti-viral immunity was first demonstrated by the discovery that patients with a congenital deficiency of NK cells have overwhelming viral infections ${ }^{62}$. This was supported by previous data where decreased NK cell function was associated with exacerbated viral infections in transplant patients ${ }^{63}$. Two groups have identified an autosomal recessive trait that involves a mutation of mini-chromosome maintenance-deficient 4 (MCM4) gene, this results in a truncated protein p.Pro24Argfs $X 4^{64,}{ }^{65}$. Phenotypically, this results in adrenal insufficiency, short stature and NK cell deficiency. These patients were also more susceptible to severe viral infections, further confirming the role of NK cells ${ }^{64,65}$. Viral infections, in particular, CMV and respiratory infections, often pose a particular danger for patients following $\mathrm{HSCT}^{66-68}$. Extensive studies have been done in understanding the role of NK cells in clearing CMV and how this virus evades the innate immune responses ${ }^{69,70}$. (Table 3). Therefore, in this section we will focus on the role of NK cells during CMV infection.

NK cells play a large role in the control of CMV infection. Much of this work has been done in mice, using murine CMV (MCMV) models. When a mouse is infected by MCMV, the infected cells present m157, a protein similar to HLA class I molecules ${ }^{71}$. This interacts with $\mathrm{Ly} 49 \mathrm{H}$, which is an activation receptor on the surface of murine NK cells analogous to $\mathrm{KIR}^{71,72}$. Depending on the strain of mice, the function of $\mathrm{m} 157$ 
can be either an activating or inhibitory ${ }^{71}$. In the B6 mouse, m157 interacts with activating Ly49H, which allows the NK cells to control $\mathrm{MCMV}^{73}$. In other mouse strains, different receptors in the Ly 49 family are involved $^{69}$. This control is mediated through secretion of IFN- $\gamma$ as well as direct cytotoxicity ${ }^{70}$. Interestingly, it has been found that MCMV can overcome even a lack of 'education' of the NK cells, so in the event the NK cell has not yet encountered MHC class I antigen, which allows it to be activated, the NK cell can still mediate effector functions against $\mathrm{MCMV}^{12}$.

Also, NK cells play a protective role in CMV reactivation and infection following HSCT. There is evidence that NK cells proliferate during CMV viremia in solid organ transplant patients, as evidenced by a higher frequency of NK cells with increased CD57, decreased NGK2A and high Ki-67 ${ }^{14}$. Zaia et al demonstrated that expressing activating KIR2DS2 and KIR2DS4 was protective against CMV reactivation ${ }^{74}$. This protective role was confirmed by another study from that group that demonstrated that increased expression of KIR2DS2 and KIR2DS4, as determined by analyzing the quantity of respective messenger RNA, was associated with decreased CMV reactivation $^{14}$. Several studies have demonstrated that the presence of more than one activating KIR was associated with a reduction of CMV reactivation in HLA-matched sibling donors ${ }^{75-77}$. Whereas, the number of activating KIR expressed appears to impact CMV reactivation ${ }^{74}$, viral infections were not found to be affected by donor haplotype in unrelated donors ${ }^{78}$.

Interestingly, CMV sero-positivity and reactivation may also help shape the NK cell repertoire. Several groups have demonstrated an increase in

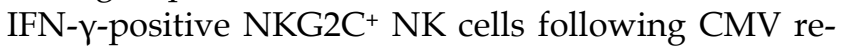

activation in patients who had undergone umbilical cord blood transplant ${ }^{16,79}$ and HLA-matched related and unrelated transplants ${ }^{17}$ These NK cells also demonstrate high levels of activating KIR, and a more mature phenotype ${ }^{16}$. Expansion of $\mathrm{NKG}^{2} \mathrm{C}^{+} \mathrm{NK}$ cells has also been observed in non-transplant patients with exposure to $\mathrm{CMV}^{26,80}$. In summary, NK cells appear to play a protective role against CMV following HSCT. Number of activating KIR expressed, in particular KIR2DS2 and KIR2DS4, help mediate the protection. There is also evidence that CMV infection may help shape KIR repertoire, evidenced by the presence of NK cells with a more mature phenotype following CMV infection.

\section{NK cells play a vital role in tissue regen- eration}

One of the less explored clinical aspects of NK cell effector functions is their ability to produce cytokines that are directly involved in tissue regeneration. Following HSCT, both GVHD and infections can result in mucosal and epithelial destruction. Of infections, community acquired respiratory infections can result in significant morbidity and mortality. Based on data from our laboratory ${ }^{4}$, NK cells likely play a role in both mediating anti-microbial effects as well as providing support for tissue regeneration. The role of NK and NK-like cells in mucosal immunity is an area of active investigation. Many studies have demonstrated NK and NK-like cells that produce IL-22 are present in the intestine, tonsils, and other mucosal organs ${ }^{81-88}$. IL-22 acts primarily on epithelial cells, resulting in increased repair and proliferation, as well as production of anti-microbial proteins ${ }^{89}$.

Table 3. Allogeneic bone marrow transplantation and NK cell-mediated anti-viral immunity.

\begin{tabular}{|c|c|c|c|c|c|}
\hline Reference & $\mathrm{N}$ & Measurement & $\begin{array}{l}\text { T replete/ } \\
\text { deplete }\end{array}$ & $\begin{array}{c}\text { Transplant } \\
\text { characteristics }\end{array}$ & Observations \\
\hline \multirow[t]{2}{*}{ Sobecks et al $2011^{61}$} & \multirow[t]{2}{*}{64} & \multirow{2}{*}{$\begin{array}{l}\text { Activating KIR- absolute } \\
\#-\end{array}$} & \multirow[t]{2}{*}{ T replete } & Flu-TBI & \multirow{2}{*}{$\begin{array}{l}\text { Less CMV reactivation with 5-6 activating KIR vs } \\
1-4\end{array}$} \\
\hline & & & & MRD & \\
\hline Tomblyn et al. $2009^{62}$ & 116 & Kir haplotype A/A or B/x & Both & All & $\begin{array}{l}\text { No difference in fungal infections or CMV. De- } \\
\text { crease in bacterial infections with haplotype } B / x\end{array}$ \\
\hline \multirow[t]{2}{*}{ Zaia et al. 200959} & \multirow[t]{2}{*}{211} & \multirow[t]{2}{*}{ Activating KIR } & \multirow[t]{2}{*}{ T replete } & MRD/URD & \multirow{2}{*}{$\begin{array}{l}\text { Less CMV with either }>5 \text { activating KIR, OR pres- } \\
\text { ence of KIR2DS2 + KIR2DS4 }\end{array}$} \\
\hline & & & & MA/RIC & \\
\hline Cook et al. $2006^{26}$ & 234 & $\begin{array}{l}\text { KIR haplotype B/x vs } \\
\text { other }\end{array}$ & Both & Both & Less CMV with KIR haplotype B/x \\
\hline Chen et al $2006^{60}$ & 131 & Activating KIR & T replete & MA & $\begin{array}{l}\text { No difference in haplotype, but if donor has addi- } \\
\text { tional activating KIR, less CMV }\end{array}$ \\
\hline Schaffer et al $2004^{37}$ & 190 & KIR-L MM & Both & Both & Increased infections with KIR L MM \\
\hline $\begin{array}{l}\text { Bornhauser et al } \\
2004^{41}\end{array}$ & 118 & KIR-L MM & Both & Both & Increased infection with KIR L MM \\
\hline
\end{tabular}


Both conventional NK cells and NK-like cells contribute to mucosal immunity. In the gut, NK-like cells display an immature conventional NK phenotype and are characterized by several unique features. They are dependent on transcription factor RORyt, and do not require IL-15 for their development. These cells also produce abundant IL-22 but do not secrete high levels of IFN- $\gamma$ and granzyme ${ }^{90}$. A similar subset has been described in human tonsils ${ }^{81}$. However, in our laboratory and others, the NK cells responsible for IL-22 in the lung have a more conventional phenotype, in that they are IL-15 dependent, and display a more mature NK phenotype ${ }^{4,82}$.

NK cells play a crucial role in the control of influenza infection. This was first described almost 30 years ago, and has been an active area of research ${ }^{91}$. The hemagglutinin (HA) expressed on the surface of infected cells binds to NKp46 ${ }^{92-96}$. This control is mediated by both release of IFN- $\gamma$ and modulation of dendritic cells, as well as direct cytotoxicity of infected cells $^{82,92,94,97,98}$. Further, in a murine model, depletion of NK cells increases mortality from the influenza virus $^{99}$. Our recent studies demonstrate that in addition to controlling infection, NK cells play a critical role in epithelial cell regeneration. We have demonstrated the importance of NK cells in epithelial regeneration in a murine influenza model, specifically through production of IL- $22^{4}$. We found that IL-22 $2^{-/}$ mice had significantly higher morbidity and mortality during influenza infection when compared to that of wild type mice. This is reversed by adoptively infusing the IL-22 $2^{-/}$mice with IL-22-sufficient NK cells ${ }^{4}$. This data suggests that conventional NK cells in the lung may play both anti-infective as well as pro-regenerative roles. This finding is supported by previous studies demonstrating protective role of NK cells against Staphylococcus aureus infection following influenza infection, which is postulated to be due to improved epithelial cell regeneration, and production of anti-bacterial peptides ${ }^{100}$. These peptides, $\beta$-defensins 1 and 2, are thought to be secreted by epithelial cells in response to IL-2287. Another group has also demonstrated the protective role of IL-22 in influenza infections, though they report it is secreted by invariant NKT cells, rather than conventional NK cells ${ }^{84}$.

Most of what is known regarding human NK cells during influenza infection has been derived from in vitro studies using peripheral blood ${ }^{93,98}$. Although that data provides meaningful information regarding the interaction of NK cells with dendritic cells (DC), it is unclear whether that provides insight into what is happening in the respiratory mucosa. There is evidence that in particular NK cells play a role in muco- sal immunity against influenza. One study evaluated NK cells in nasal lavage of smokers following live attenuated influenza vaccine (LAIV), and found that although the NK cell numbers were not altered, they appeared to have a different phenotype in smokers as compared to non-smokers ${ }^{101}$. In non-smokers, the $\mathrm{CD}_{56}{ }^{\text {dim }}{ }^{-} \mathrm{CD} 16^{+}$had higher levels of granzyme $\mathrm{B}$, suggesting improved cytotoxic function as compared to non-smokers ${ }^{101}$. These differences were not appreciated in the peripheral blood analysis ${ }^{101}$. The cells were not analyzed for their functional capacity, so it is unclear what their abilities are relating to cytotoxicity, cytokine secretion, or mucosal repair ${ }^{4}$. The NK subset identified in human tonsils preferentially secretes IL-22 and CCL20 but not IFN- $\gamma^{81}$. These cells also do not have high amounts of granzyme B, suggesting their cytotoxic effect is limited, and appear to be similar to the NK-like cells described in the intestinal mucosa. Although this data is intriguing, it is limited, and the identification of NK cell subsets that are present in different human tissues warrant further investigations.

\section{NK cells as potential modulators of GVHD}

NK cells may provide a regulatory role following allogeneic stem cell transplant. Several studies have demonstrated reduced GVHD thought to be mediated by NK cells ${ }^{36-38,102,103}$. Rivas et al have demonstrated the ability of NK cells to lyse chronically active CD4+ $\mathrm{T}$ cells in a murine model, thought to represent a potential ability to control chronic GVHD ${ }^{104}$. Only possible mechanism involves NK cell DNAX accessory molecule-1 (DNAM-1) interactions with T cell markers CD155 and CD161 ${ }^{105}$, this interaction results in lysis of activated T cells. Another possible mechanism involves interaction between NKG2D receptor and T cell marker H60, which also results in destruction of activated $\mathrm{T}$ cells ${ }^{106}$. Other studies suggest that NK cells may control CD8 proliferation by competing for IL-15 ${ }^{107}$. NK cell may also lyse dendritic cells, which are implicated in $\mathrm{GVHD}^{108}$.

\section{NK cells and gut GVHD}

NK cell subsets in the intestinal mucosa may play a critical role in development of intestinal GVHD, as well as the regeneration of intestinal mucosa. In the mouse, there have been two subsets of NK cells identified ${ }^{109}$. One subset shares features with conventional NK cells in that these cells are IL-15 dependent, demonstrate cytotoxic capabilities, secrete high levels of IFN- $\gamma$, and have high expression of NKp46, NK1.1, and NKG2D ${ }^{109}$. The other subset is 
considered either lymphoid tissue inducer (LTi) cells or NK-LTi. These cells are IL-15 independent, but rely on RORYt for their development, the primary function being the secretion of IL-22 ${ }^{109}$. This subset is protective against infections that can affect the intestines ${ }^{109}$, ${ }^{110}$, including strains of bacteria, such as Citrobacter rodentium in the mouse, which is similar to Escherichia coli in humans ${ }^{111}$. Although subsets of $\mathrm{T}$ cells can produce IL- $22^{89}$, the significant levels of IL-22 produced during Citrobactor rodentium infection in Rag2 $2^{--}$ mice, suggests that it is less likely to be of $\mathrm{T}$ cell origin ${ }^{111}$. Given that abundant NK cells are present in the intestine, there is interest in the role of IL-22 in intestinal GVHD.

\section{Future prospects}

NK cells play a critical role in HSCT in both anti-tumor as well as anti-microbial immune responses. There is still much to be learned about novel NK cell functions and developmental regulation of donor progenitor NK cells inside the patient bone marrow. One particularly interesting component of NK cells relates to their dual nature, at times appearing to stimulate the immune system, and other times they regulate immunes response to control the immune system. This difference in function is critical to understand, in particular when considering therapeutic interventions. Their regulatory abilities deserve further evaluation, and could be harnessed to help control GVHD. Another area of interest is the role of NK cells in mucosal immunity. In murine models, a subset of pulmonary NK cells provides both conventional NK cell functions and novel regenerative properties through their ability to secrete IL-22. Given the substantial morbidity and mortality due to respiratory viral infections following HSCT $^{67,112-116}$, understanding the role of NK cell subsets in the lung on anti-viral immunity would potentially lead to therapeutic interventions.

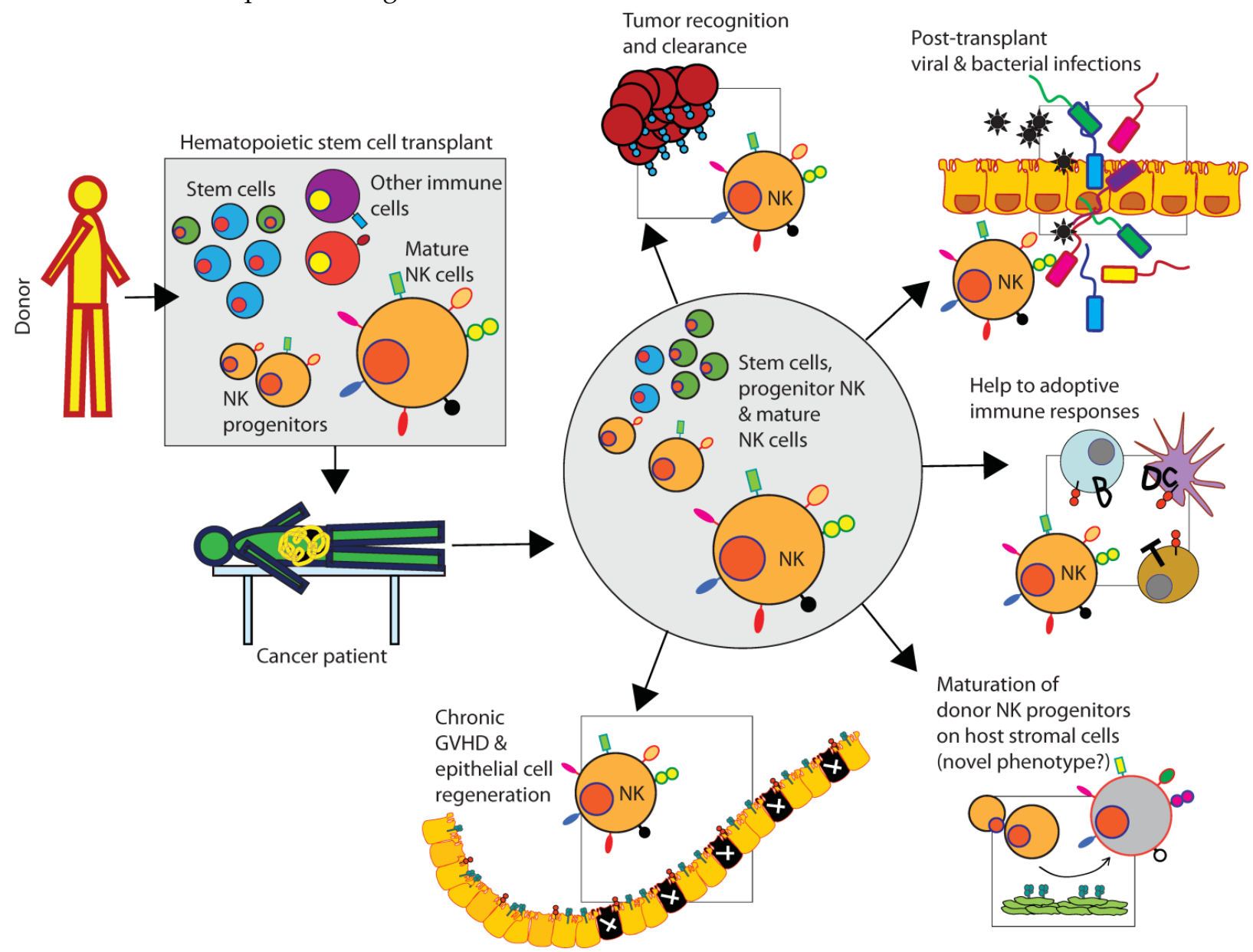

Figure I. Clinical relevance of donor-derived NK cells in patients following HSCT. Donor-derived bone marrow contains stems cells, immune cells including immature and mature NK cells. Mature NK cells recognize tumor cells and kill, mediate innate immune responses to prevent viral and bacterial infections, and provide help to $T$ and $B$ cells to coordinate the anti-tumor adoptive immune responses. Additionally, donor-derived stem cells can acquire a distinct NK phenotype by maturing in the host (patient) HLA environment. NK cells can also participate in the regeneration of tissues including the epithelial cell layers. 


\section{Competing Interests}

The authors have declared that no competing interest exists.

\section{References}

1. See DM, Khemka P, Sahl L, Bui T, Tilles JG. The Role of Natural Killer Cells in Viral Infections. Scand J Immunol. 1997;46:217-224.

2. Fildes JE, Yonan N, Leonard CT. Natural killer cells and lung transplantation, roles in rejection, infection, and tolerance. Transpl Immunol. 2008;19:1-11.

3. Farag SS and Caligiuri MA. Human natural killer cell development and biology. Blood Rev. 2006;20:123-137.

4. Kumar P, Thakar M, Ouwang W, Malarkannan S. IL-22 from conventional NK cells regulate lung epithelial cell regeneration. Mucosal Immunology. 2012.

5. Storek J, Dawson MA, Storer B, et al. Immune reconstitution after allogeneic marrow transplantation compared with blood stem cell transplantation. Blood 2001;97:3380-3389.

6. Small TN, Papadopoulos EB, Boulad F, et al. Comparison of Immune Reconstitution After Unrelated and Related T-Cell-Depleted Bone Marrow Transplantation: Effect of Patient Age and Donor Leukocyte Infusions. Blood. 1999;93:467-480.

7. Crellin NK, Trifari S, Kaplan CD, Cupedo T, Spits H. Human NKp44+IL-22+ cells and LTi-like cells constitute a stable RORC+ lineage distinct from conventional natural killer cells. The Journal of Experimental Medicine. 2010;207:281-290.

8. Cupedo T, Crellin NK, Papazian N, et al. Human fetal lymphoid tissue-inducer cells are interleukin 17-producing precursors to $\mathrm{RORC}^{+}$ $\mathrm{CD}_{127}{ }^{+}$natural killer-like cells. Nature Immunology. 2008;10:66-74.

9. Haas P, Loiseau P, Tamouza R, et al. NK-cell education is shaped by donor HLA genotype after unrelated allogeneic hematopoietic stem cell transplantation. Blood. 2011;117:1021-1029.

10. Strowig T, Chijioke O, Carrega P, et al. Human NK cells of mice with reconstituted human immune system components require preactivation to acquire functional competence. Blood. 2010;116:4158-4167.

11. Anfossi N, André P, Guia S, et al. Human NK Cell Education by Inhibitory Receptors for MHC Class I. Immunity. 2006;25:331-342.

12. Sun JC and Lanier LL. Cutting Edge: Viral Infection Breaks NK Cell Tolerance to "Missing Self". The Journal of Immunology. 2008;181:7453-7457.

13. Foley B, Cooley S, Verneris MR, et al. NK cell education after allogeneic transplantation: dissociation between recovery of cytokine-producing and cytotoxic functions. Blood. 2011;118:2784-2792.

14. Gallez-Hawkins GM, Franck AE, Li X, et al. Expression of activating KIR2DS2 and KIR2DS4 genes after hematopoietic cell transplantation: Relevance to cytomegalovirus infection. Biology of Blood and Marrow Transplantation. 2011;17:1662-1672.

15. Gill S, Olson JA, Negrin RS. Natural Killer Cells in Allogeneic Transplantation: Effect on Engraftment, Graft- versus-Tumor, and Graft-versus-Host Responses. Biology of Blood and Marrow Transplantation. 2009;15:765-776.

16. Foley B, Cooley S, Verneris MR, et al. Cytomegalovirus reactivation after allogeneic transplantation promotes a lasting increase in educated NKG2C + natural killer cells with potent function. Blood. 2012;119:2665-2674

17. Muñoz-Cobo B, Solano C, Benet I, et al. Functional profile of cytomegalovirus (CMV)-specific CD8+ T cells and kinetics of NKG2C+ NK Cells associated with the resolution of CMV DNAemia in allogeneic stem cell transplant recipients. J Med Virol. 2012;84:259-267.

18. Gilfillan S, Ho EL, Cella M, Yokoyama WM, Colonna M. NKG2D recruits two distinct adapters to trigger NK cell activation and costimulation. Nature Immunology. 2002;3:1150-1155.

19. Hayakawa Y, Huntington ND, Nutt SL, Smyth MJ. Functional subsets of mouse natural killer cells. Immunol Rev. 2006;214:47-55.

20. Romagnani C, Juelke K, Falco M, et al. CD56brightCD16- Killer Ig-Like Receptor- NK Cells Display Longer Telomeres and Acquire Features of CD56dim NK Cells upon Activation. The Journal of Immunology. 2007;178:4947-4955.

21. Shilling HG, Young N, Guethlein LA, et al. Genetic Control of Human NK Cell Repertoire. The Journal of Immunology. 2002;169:239-247.

22. Shilling HG, Guethlein LA, Cheng NW, et al. Allelic Polymorphism Synergizes with Variable Gene Content to Individualize Human KIR Genotype. The Journal of Immunology. 2002;168:2307-2315.
23. Uhrberg M, Valiante NM, Shum BP, et al. Human Diversity in Killer Cell Inhibitory Receptor Genes. Immunity. 1997;7:753-763.

24. Björklund AT, Schaffer M, Fauriat C, et al. NK cells expressing inhibitory KIR for non-self-ligands remain tolerant in HLA-matched sibling stem cell transplantation. Blood. 2010;115:2686-2694.

25. Cooley S, Xiao F, Pitt M, et al. A subpopulation of human peripheral blood NK cells that lacks inhibitory receptors for self-MHC is developmentally immature. Blood. 2007;110:578-586.

26. Lopez-Vergès $S$, Milush JM, Schwartz BS, et al. Expansion of a unique CD57+NKG2Chi natural killer cell subset during acute human cytomegalovirus infection. Proceedings of the National Academy of Sciences. 2011;108:14725-14732.

27. Dulphy N, Haas P, Busson M, et al. An Unusual CD56brightCD16low NK Cell Subset Dominates the Early Posttransplant Period following HLA-Matched Hematopoietic Stem Cell Transplantation. The Journal of Immunology. 2008;181:2227-2237.

28. Nguyen S, Dhedin N, Vernant J, et al. NK-cell reconstitution after haploidentical hematopoietic stem-cell transplantations: immaturity of NK cells and inhibitory effect of NKG2A override GvL effect. Blood. 2005; 105:4135-4142.

29. Malmberg $K$, Schaffer $M$, Ringdén $O$, Remberger $M$, Ljunggren $H$. KIR-ligand mismatch in allogeneic hematopoietic stem cell transplantation. Mol Immunol. 2005;42:531-534.

30. Björkström NK, Riese P, Heuts F, et al. Expression patterns of NKG2A, KIR, and CD57 define a process of CD56dim NK-cell differentiation uncoupled from NK-cell education. Blood. 2010;116:3853-3864.

31. Yu J, Heller G, Chewning J, Kim S, Yokoyama WM, Hsu KC. Hierarchy of the Human Natural Killer Cell Response Is Determined by Class and Quantity of Inhibitory Receptors for Self-HLA-B and HLA-C Ligands. The Journal of Immunology. 2007;179:5977-5989.

32. Haas J, Fritzsching B, Trubswetter P, et al. Prevalence of Newly Generated Naive Regulatory $\mathrm{T}$ Cells (Treg) Is Critical for Treg Suppressive Function and Determines Treg Dysfunction in Multiple Sclerosis. J Immunol 2007;179:1322-1330.

33. Shilling HG, McQueen KL, Cheng NW, Shizuru JA, Negrin RS, Parham P. Reconstitution of NK cell receptor repertoire followingHLA-matched hematopoietic cell transplantation. Blood. 2003;101:3730-3740.

34. Andersson S, Fauriat C, Malmberg J, Ljunggren H, Malmberg K. KIR acquisition probabilities are independent of self-HLA class I ligands and increase with cellular KIR expression. Blood. 2009;114:95-104.

35. Gumperz JE, Valiante NM, Parham P, Lanier LL, Tyan D. Heterogeneous phenotypes of expression of the NKB1 natural killer cell class I receptor among individuals of different human histocompatibility leukocyte antigens types appear genetically regulated, but not linked to major histocompatibililty complex haplotype. The Journal of Experimental Medicine. 1996;183:1817-1827.

36. Ruggeri L, Capanni M, Casucci M, et al. Role of Natural Killer Cell Alloreactivity in HLA-Mismatched Hematopoietic Stem Cell Transplantation. Blood. 1999;94:333-339.

37. Ruggeri L, Capanni M, Urbani E, et al. Effectiveness of donor natural killer cell aloreactivity in mismatched hematopoietic transplants. Science. 2002;295:2097-2100.

38. Ruggeri L, Mancusi A, Capanni M, et al. Donor natural killer cell allorecognition of missing self in haploidentical hematopoietic transplantation for acute myeloid leukemia: challenging its predictive value. Blood. 2007;110:433-440.

39. Chen DF, Prasad VK, Broadwater G, et al. Differential impact of inhibitory and activating Killer Ig-Like Receptors (KIR) on high-risk patients with myeloid and lymphoid malignancies undergoing reduced intensity transplantation from haploidentical related donors. Bone Marrow Transplantation. 2012;47:817-823.

40. Venstrom JM, Gooley TA, Spellman S, et al. Donor activating KIR3DS1 is associated with decreased acute GVHD in unrelated allogeneic hematopoietic stem cell transplantation. Blood. 2010;115:3162-3165.

41. Willemze R, Rodrigues CA, Labopin M, et al. KIR-ligand incompatibility in the graft-versus-host direction improves outcomes after umbilical cord blood transplantation for acute leukemia. Leukemia. 2009;23:492-500.

42. Beelen DW, Ottinger HD, Ferencik S, et al. Genotypic inhibitory killer immunoglobulin-like receptor ligand incompatibility enhances the long-term antileukemic effect of unmodified allogeneic hematopoietic stem cell transplantation in patients with myeloid leukemias. Blood. 2005;105:2594-2600.

43. Farag SS, Bacigalupo A, Eapen M, et al. The Effect of KIR Ligand Incompatibility on the Outcome of Unrelated Donor Transplantation: A Report from the Center for International Blood and Marrow Transplant Research, the European Blood and Marrow Transplant Registry, and the 
Dutch Registry. Biology of Blood and Marrow Transplantation. 2006;12:876-884.

44. Hsu KC, Keever-Taylor CA, Wilton A, et al. Improved outcome in HLA-identical sibling hematopoietic stem-cell transplantation for acute myelogenous leukemia predicted by KIR and HLA genotypes. Blood. 2005;105:4878-4884.

45. Giebel S, Locatelli F, Lamparelli T, et al. Survival advantage with KIR ligand incompatibility in hematopoietic stem cell transplantation from unrelated donors. Blood. 2003;102:814-819.

46. Giebel S, Nowak I, Dziaczkowska J, et al. Activating killer immunoglobulin-like receptor incompatibilities enhance graft-versus-host disease and affect survival after allogeneic hematopoietic stem cell transplantation. Eur J Haematol. 2009;83:343-356.

47. Davies SM, Ruggieri L, DeFor T, et al. Evaluation of KIR ligand incompatibility in mismatched unrelated donor hematopoietic transplants. Blood. 2002;100:3825-3827.

48. Schaffer M, Malmberg K-, Ringdén O, Ljunggren H-, Remberger M. Increased infection-related mortality in KIR-ligand-mismatched unrelated allogeneic hematopoietic stem-cell transplantation. Transplantation. 2004;78:1081-1085.

49. Brunstein CG, Wagner JE, Weisdorf DJ, et al. Negative effect of KIR alloreactivity in recipients of umbilical cord blood transplant depends on transplantation conditioning intensity. Blood. 2009;113:5628-5634.

50. Miller JS, Cooley S, Parham P, et al. Missing KIR ligands are associated with less relapse and increased graft-versus-host disease (GVHD) following unrelated donor allogeneic HCT. Blood. 2007;109:5058-5061.

51. Cooley S, Weisdorf DJ, Guethlein LA, et al. Donor selection for natural killer cell receptor genes leads to superior survival after unrelated transplantation for acute myelogenous leukemia. Blood. 2010;116:2411-2419.

52. Cooley S, Trachtenberg E, Bergemann TL, et al. Donors with group B KIR haplotypes improve relapse-free survival after unrelated hematopoietic cell transplantation for acute myelogenous leukemia. Blood. 2009;113:726-732

53. Bornhäuser $M$, Schwerdtfeger $R$, Martin H, Frank $K$, Theuser $C$, Ehninger G. Role of KIR ligand incompatibility in hematopoietic stem cell transplantation using unrelated donors. Blood. 2004;103:2860-2861.

54. Dupont B and Hsu KC. Inhibitory killer Ig-like receptor genes and human leukocyte antigen class I ligands in haematopoietic stem cell transplantation. Curr Opin Immunol. 2004;16:634-643.

55. Hsu KC, Liu X, Selvakumar A, Mickelson E, O’Reilly RJ, Dupont B. Killer Ig-Like Receptor Haplotype Analysis by Gene Content: Evidence for Genomic Diversity with a Minimum of Six Basic Framework Haplotypes, Each with Multiple Subsets. The Journal of Immunology. 2002;169:5118-5129.

56. Cooley S, McCullar V, Wangen R, et al. KIR reconstitution is altered by $\mathrm{T}$ cells in the graft and correlates with clinical outcomes after unrelated donor transplantation. Blood. 2005;106:4370-4376.

57. Pfeiffer MM, Feuchtinger T, Teltschik $\mathrm{H}$, et al. Reconstitution of natural killer cell receptors influences natural killer activity and relapse rate after haploidentical transplantation of T- and B-cell depleted grafts in children. Haematologica. 2010;95:1381-1388.

58. Miller JS, Weisdorf DJ, Burns LJ, et al. Lymphodepletion followed by donor lymphocyte infusion (DLI) causes significantly more acute graft-versus-host disease than DLI alone. Blood. 2007;110(7):2761-3..

59. Eissens DN, Van Der Meer A, Van Cranenbroek B, Preijers FWMB, Joosten I. Rapamycin and MPA, But Not CsA, Impair Human NK Cell Cytotoxicity Due to Differential Effects on NK Cell Phenotype. American Journal of Transplantation. 2010;10:1981-1990.

60. Wang H, Grzywacz B, Sukovich D, et al. The unexpected effect of cyclosporin A on CD56+CD16- and CD56+CD16+ natural killer cell subpopulations. Blood. 2007;110:1530-1539.

61. Kim T, Kim N, Kang HJ, et al. FK506 causes cellular and functional defects in human natural killer cells. Journal of Leukocyte Biology. 2010;88:1089-1097.

62. Biron CA, Byron KS, Sullivan JL. Severe Herpesvirus Infections in an Adolescent without Natural Killer Cells. N Engl J Med. 1989;320:1731-1735.

63. Quinnan GV, Kirmani N, Rook AH, et al. Cytotoxic T Cells in Cytomegalovirus Infection. N Engl J Med. 1982;307:7-13.

64. Gineau L, Cognet C, Kara N, et al. Partial MCM4 deficiency in patients with growth retardation, adrenal insufficiency, and natural killer cell deficiency. Journal of Clinical Investigation. 2012;122:821-832.

65. Hughes CR, Guasti L, Meimaridou E, et al. MCM4 mutation causes adrenal failure, short stature, and natural killer cell deficiency in humans. Journal of Clinical Investigation. 2012;122:814-820.
66. Tomblyn M, Chiller T, Einsele H, et al. Guidelines for Preventing Infectious Complications among Hematopoietic Cell Transplantation Recipients: A Global Perspective. Biology of Blood and Marrow Transplantation. 2009;15:1143-1238.

67. Peck AJ, Englund JA, Kuypers J, et al. Respiratory virus infection among hematopoietic cell transplant recipients: evidence for asymptomatic parainfluenza virus infection. Blood. 2007;110:1681-1688.

68. Nichols WG, Gooley T, Boeckh M. Community-acquired respiratory syncytial virus and parainfluenza virus infections after hematopoietic stem cell transplantation: The Fred Hutchinson Cancer Research Center experience. Biology of Blood and Marrow Transplantation. 2001;7:11S-15S.

69. Vidal SM, Pyzik M, Gendron-Pontbriand E-. The impact of Ly49-NK cell-dependent recognition of MCMV infection on innate and adaptive immune responses. Journal of Biomedicine and Biotechnology. 2011.

70. Loh J, Chu DT, O'Guin AK, Yokoyama WM, Virgin HW. Natural Killer Cells Utilize both Perforin and Gamma Interferon To Regulate Murine Cytomegalovirus Infection in the Spleen and Liver. Journal of Virology. 2005;79:661-667.

71. Arase H, Mocarski ES, Campbell AE, Hill AB, Lanier LL. Direct Recognition of Cytomegalovirus by Activating and Inhibitory NK Cell Receptors. Science. 2002;296:1323-1326.

72. Brown MG, Dokun AO, Heusel JW, et al. Vital Involvement of a Natural Killer Cell Activation Receptor in Resistance to Viral Infection. Science. 2001;292:934-937.

73. Scalzo AA, Fitzgerald NA, Simmons A, La Vista AB, Shellam GR. Cmv-1, a genetic locus that controls murine cytomegalovirus replication in the spleen. The Journal of Experimental Medicine. 1990;171:1469-1483.

74. Zaia JA, Sun JY, Gallez-Hawkins GM, et al. The Effect of Single and Combined Activating Killer Immunoglobulin-like Receptor Genotypes on Cytomegalovirus Infection and Immunity after Hematopoietic Cell Transplantation. Biology of Blood and Marrow Transplantation. 2009;15:315-325.

75. Cook M, Briggs D, Craddock C, et al. Donor KIR genotype has a major influence on the rate of cytomegalovirus reactivation following T-cell replete stem cell transplantation. Blood. 2006;107:1230-1232.

76. Chen C, Busson M, Rocha V, et al. Activating KIR genes are associated with CMV reactivation and survival after non-T-cell depleted HLA-identical sibling bone marrow transplantation for malignant disorders. Bone Marrow Transplant. 2006;38:437-444.

77. Sobecks RM, Askar M, Thomas D, et al. Cytomegalovirus reactivation after matched sibling donor reduced-intensity conditioning allogeneic hematopoietic stem cell transplant correlates with donor killer immunoglobulin-like receptor genotype. Experimental and Clinical Transplantation. 2011;9:7-13.

78. Tomblyn M, Young JH, Haagenson MD, et al. Decreased Infections in Recipients of Unrelated Donor Hematopoietic Cell Transplantation from Donors with an Activating KIR Genotype. Biology of Blood and Marrow Transplantation. 2010;16:1155-1161.

79. Della Chiesa M, Falco M, Podestà $\mathrm{M}$, et al. Phenotypic and functional heterogeneity of human NK cells developing after umbilical cord blood transplantation: a role for human cytomegalovirus? Blood. 2012;119:399-410.

80. Gumá M, Budt M, Sáez A, et al. Expansion of CD94/NKG2C+ NK cells in response to human cytomegalovirus-infected fibroblasts. Blood. 2006;107:3624-3631.

81. Cella M, Fuchs A, Vermi W, et al. A human natural killer cell subset provides an innate source of IL-22 for mucosal immunity. Nature. 2009;457:722-725

82. Guo H and Topham DJ. Interleukin-22 (IL-22) Production by Pulmonary Natural Killer Cells and the Potential Role of IL-22 during Primary Influenza Virus Infection. Journal of Virology. 2010;84:7750-7759.

83. Li F, Zhu H, Sun R, Wei H, Tian Z. Natural Killer Cells Are Involved in Acute Lung Immune Injury Caused by Respiratory Syncytial Virus Infection. Journal of Virology. 2012;86:2251-2258.

84. Paget $\mathrm{C}$, Ivanov $\mathrm{S}$, Fontaine J, et al. Interleukin-22 is produced by invariant natural killer $\mathrm{T}$ lymphocytes during influenza A virus infection: potential role in protection against lung epithelial damage. Journal of Biological Chemistry. 2012.

85. Satoh-Takayama N, Lesjean-Pottier S, Sawa S, Vosshenrich CAJ, Eberl G, Di Santo JP. Lymphotoxin-? receptor-independent development of intestinal IL-22-producing NKp46+ innate lymphoid cells. Eur J Immunol. 2011;41:780-786.

86. Sonnenberg G, Fouser LA, Artis D. Border patrol: regulation of immunity, inflammation and tissue homeostasis at barrier surfaces by IL-22. Nature Immunology. 2011;12:383-390. 
87. Witte E, Witte K, Warszawska K, Sabat R, Wolk K. Interleukin-22: A cytokine produced by T, NK and NKT cell subsets, with importance in the innate immune defense and tissue protection. Cytokine Growth Factor Rev. 2010;21:365-379.

88. Ishikawa $\mathrm{H}$, Tanaka $\mathrm{K}$, Kutsukake E, et al. IFN- $\gamma$ production downstream of NKT cell activation in mice infected with influenza virus enhances the cytolytic activities of both NK cells and viral antigen-specific CD8+ T cells. Virology. 2010;407:325-332.

89. Wolk K, Kunz S, Witte E, Friedrich M, Asadullah K, Sabat R. IL-22 Increases the Innate Immunity of Tissues. Immunity. 2004;21:241-254.

90. Luci C, Ana Reynder A, Ivanov II, et al. Influence of the transcription factor RORt on the development of $\mathrm{NKp} 46^{+}$cell populations in gut and skin. Nature Immunology. 2008;10:75-82.

91. Stein-Streilein J, Bennett M, Mann D, Kumar V. Natural killer cells in mouse lung: surface phenotype, target preference, and response to local influenza virus infection. The Journal of Immunology. 1983;131:2699-2704.

92. Jost S, Reardon J, Peterson E, et al. Expansion of 2B4+ natural killer (NK) cells and decrease in NKp46+ NK cells in response to influenza. Immunology. 2011;132:516-526.

93. Lin S, Cheng P, Lin T, Lee P, Hsiao H, Kuo M. Effect of Influenza A Infection on Umbilical Cord Blood Natural Killer Function Regulation With Interleukin-15. Journal of Infectious Diseases. 2012;205:745-756.

94. Guo H, Kumar P, Malarkannan S. Evasion of natural killer cells by influenza virus. Journal of Leukocyte Biology. 2011;89:189-194.

95. Arnon TI, Lev M, Katz G, Chernobrov Y, Porgador A, Mandelboim O. Recognition of viral hemagglutinins by NKp44 but not by NKp30. Eur J Immunol. 2001;31:2680-2689.

96. Mandelboim O, Lieberman N, Lev M, et al. Recognition of haemagglutinins on virus-infected cells by NKp46 activates lysis by human NK cells. Nature. 2001;409:1055-1060.

97. Guo H, Kumar P, Moran TM, Garcia-Sastre A, Zhou Y, Malarkannan S. The functional impairment of natural killer cells during influenza virus infection. Immunology and Cell Biology. 2009;87:579-589.

98. Draghi M, Pashine A, Sanjanwala B, et al. NKp46 and NKG2D Recognition of Infected Dendritic Cells Is Necessary for NK Cell Activation in the Human Response to Influenza Infection. The Journal of Immunology. 2007;178:2688-2698

99. Stein-Streilein J and Guffee J. In vivo treatment of mice and hamsters with antibodies to asialo GM1 increases morbidity and mortality to pulmonary influenza infection. The Journal of Immunology. 1986;136:1435-1441.

100. Small C, Shaler CR, McCormick S, et al. Influenza Infection Leads to Increased Susceptibility to Subsequent Bacterial Superinfection by Impairing NK Cell Responses in the Lung. The Journal of Immunology. 2010;184:2048-2056.

101. Horvath KM, Herbst M, Zhou H, Zhang H, Noah TL, Jaspers I. Nasal lavage natural killer cell function is suppressed in smokers after live attenuated influenza virus. Respiratory Research. 2011;12:102.

102. Aversa F, Terenzi A, Tabilio A, et al. Full Haplotype-Mismatched Hematopoietic Stem-Cell Transplantation: A Phase II Study in Patients With Acute Leukemia at High Risk of Relapse. J Clin Oncol. 2005;23(15):3447-54.

103. Rizzieri DA, Koh LP, Long GD, et al. Partially Matched, Nonmyeloablative Allogeneic Transplantation: Clinical Outcomes and Immune Reconstitution. J Clin Oncol 2007;25:690-697.

104. Rivas MN, Hazzan M, Weatherly K, Gaudray F, Salmon I, Braun MY. NK Cell Regulation of CD4 T Cell-Mediated Graft-versus-Host Disease. The Journal of Immunology. 2010;184:6790-6798.

105. Ardolino M, Zingoni A, Cerboni C, et al. DNAM-1 ligand expression on Ag-stimulated T lymphocytes is mediated by ROS-dependent activation of DNA-damage response: relevance for NK-T cell interaction. Blood. 2011;117:4778-4786.

106. Rabinovich BA, Li J, Shannon J, et al. Activated, But Not Resting, T Cells Can Be Recognized and Killed by Syngeneic NK Cells. The Journal of Immunology. 2003;170:3572-3576

107. Zecher D, Li Q, Oberbarnscheidt MH, et al. NK Cells Delay Allograft Rejection in Lymphopenic Hosts by Downregulating the Homeostatic Proliferation of CD8+ $\mathrm{T}$ Cells. The Journal of Immunology. 2010;184:6649-6657.

108. Moretta L, Ferlazzo G, Bottino C, et al. Effector and regulatory events during natural killer?dendritic cell interactions. Immunol Rev. 2006;214:219-228

109. Sanos S and Diefenbach A. Isolation of NK Cels and NK-Like Cells from the Intestinal Lamina Propria. In: Campbell KS, ed. Methods in Molecular Biology: Natural Killer Cell Biology. Humana Press, a part of Springer Science+Business Media; 2010:505-517.
110. Satoh-Takayama N, Vosshenrich CAJ, Lesjean-Pottier S, et al. Microbial Flora Drives Interleukin 22 Production in Intestinal NKp46+ Cells that Provide Innate Mucosal Immune Defense. Immunity. J Clin Oncol. 2008;29:958-970.

111. Zheng Y, Valdez PA, Danilenko DM, et al. Interleukin-22 mediates early host defense against attaching and effacing bacterial pathogens. Nature Medicine. 2008;14:282-289.

112. Hassan IA, Chopra R, Swindell R, Mutton KJ. Respiratory viral infections after bone marrow//peripheral stem-cell transplantation: the Christie hospital experience1. Bone Marrow Transplant. 2003;32:73-77.

113. Bowden MDRA. Respiratory Virus Infections After Marrow Transplant: The Fred Hutchinson Cancer Research Center Experience. The American Journal of Medicine. 1997;102:27-30.

114. Whimbey E, Champlin RE, Couch RB, et al. Community respiratory virus infections among hospitalized adult bone marrow transplant recipients. Clinical Infectious Diseases. 1996;22:778-782.

115. Boeckh M, Englund J, Li Y, et al. Randomized Controlled Multicenter Trial of Aerosolized Ribavirin for Respiratory Syncytial Virus Upper Respiratory Tract Infection in Hematopoietic Cell Transplant Recipients. Clinical Infectious Diseases. 2007;44:245-249.

116. Erard V, Chien JW, Kim HW, et al. Airflow Decline after Myeloablative Allogeneic Hematopoietic Cell Transplantation: The Role of Community Respiratory Viruses. Journal of Infectious Diseases. 2006;193:1619-1625. 